\title{
Duties to Make Friends
}

\author{
Stephanie Collins
}

Accepted: 14 March 2013

(C) Springer Science+Business Media Dordrecht 2013

\begin{abstract}
Why, morally speaking, ought we do more for our family and friends than for strangers? In other words, what is the justification of special duties? According to partialists, the answer to this question cannot be reduced to impartial moral principles. According to impartialists, it can. This paper briefly argues in favour of impartialism, before drawing out an implication of the impartialist view: in addition to justifying some currently recognised special duties, impartialism also generates new special duties that are not yet widely recognised. Specifically, in certain situations, impartial principles generate duties to take actions and adopt attitudes in our personal lives that increase the chance of new or different special relationships being formed-new or different friendships, family-like relationships, relationships akin to co-nationality, and so on. In fact, even if one thinks partialism is the best justification of the duties we have once in special relationships, impartialist justifications for taking steps to form such relationships should have some sway. Moreover, a little reflection shows that these duties are not as demanding or counterintuitive as one might expect.
\end{abstract}

Keywords Special duties $\cdot$ Partiality $\cdot$ Relationships

\section{Special Relationships, Partiality, and Special Duties}

A strict definition of special relationships has eluded moral philosophers, but we can point to paradigm examples: family, friends, spouses, perhaps co-nationals. Characteristically, these relationships are not formally contracted, depend on a certain history between the parties, and are valued non-instrumentally by the parties (Scheffler 2001, ch. 6; Scheffler 1997; Kolodny 2003, 148). The participants tend

S. Collins $(\bowtie)$

School of Philosophy, Australian National University, Canberra ACT 0200, Australia

e-mail: stephanie.collins@anu.edu.au 
to take each other's interests as their own: it is good for me when something good happens to, or is done by, my relative. ${ }^{1}$ And participants usually value each other as a package: my dentist or prime minister could be replaced by someone with just a few of the same properties without a change in that role-bearer's value to me, but my spouse or friends or parents could not.

Another characteristic feature of special relationships is that the participants are partial to one another. A's being partial to B relative to C can be glossed as (all else being equal): A's deliberations give more weight to B's interests ${ }^{2}$ than they do to C's interests; A's intentions aim to promote ${ }^{3}$ B's interests and prevent what is not in B's interests to a greater degree than C's; A would choose to promote, and would take on greater costs to promote, B's interests rather than C's interests. Mutatis mutandis, partiality can extend to relationships as well as relatives: A can be partial to the A-B relationship over the A-C relationship or over the $\mathrm{C}-\mathrm{D}$ relationship. Partiality is relative: A's being partial to B requires that A's treatment of B differs from A's treatment of some C. It is therefore impossible to be partial to everyone.

Plausibly, partiality is morally permitted or required, at least in certain contexts. ${ }^{4}$ To see this, first consider reactive attitudes. Imagine a person who does not visit his senile mother in a rest home, despite living nearby, and despite the visit requiring partiality. (Suppose other residents would benefit equally from his visit and he cannot visit them all.) We criticise him. We think he has wronged his mother. ${ }^{5}$ We would feel guilty if we did as he did. These attitudes suggest a moral failing, not merely a failing of prudence, politeness, or aesthetic preferences. Second, reasons to be partial have greater weight than reasons of, say, prudence or etiquette. They are even 'presumptively decisive' reasons. ${ }^{6}$ Imagine that prudence and etiquette continually demand that the man go to work, rather than visit his mother. That these reasons can compete with partiality reasons - and that they would have to be very strong to outweigh partiality reasons - suggest that partiality reasons are of a different (and stronger) type. Third, partiality reasons are categorical for relatives: given that one is in a special relationship, one cannot avoid these reasons by changing one's aims and projects. This again gives them a moral flavour.

Moral reasons with a certain level of strength can be called 'duties.' I will therefore use the phrase 'special duties' to mean 'strong moral reasons to be partial to special relatives in certain contexts.' I appeal to intuition in motivating the thought that these duties exist, in order to motivate the search for a moral justification of them. If the search fails, perhaps we should give up on these reasons or give up on them as moral reasons. But if we can convincingly justify partiality reasons in moral terms, then the burden of proof falls back onto those who claim there are no such reasons, or that the reasons are amoral. Thankfully, there are multiple candidates for these reasons' moral justification. These justifications fall into two broad types: 'partialist' and 'impartialist.'

According to partialists, justifications for special duties contain irreducible reference to the relationship we are in with the relative, or irreducible reference to the relative themselves. In $\S 2$, I consider two kinds of partialism and suggest some problems for each. For

\footnotetext{
${ }^{1}$ Jones (2012) gives a full account of this feature within relationships of love. I will not distinguish loving special relationships from other kinds here.

2 or claims or authority or rights-fulfilment or preferences or wellbeing or...

${ }^{3}$ or preserve or protect or bring about or respect or fulfil or...

${ }^{4}$ Some (e.g. Wolf 1982) deny that partiality falls within morality's domain. Unfortunately I lack space to fully discuss this view (though see the brief discussion in $\$ 4.3$ ), and will pursue the topic from within the moral purview.

${ }^{5}$ Wellman $(1997,186-7)$ denies that one wrongs, for example, one's sister by choosing not to attend her wedding. For Wellman, the choice merely reveals one to have a bad character. Even if Wellman is correct that one does not wrong one's sister, the character-based view seems committed to a moral reason to be the kind of person that would attend her wedding (and so a moral reason to be the kind of person who is partial).

6 This phrase derives from Scheffler $(2010,196)$.
} 
impartialists, special duties' justifications are reducible to impartial principles-principles that are indifferent to whether those affected by our actions and attitudes are relatives or nonrelatives. In $\S 3$, I consider two kinds of impartialism and suggest that each is better than either kind of impartialism. I then, in $\S 4$, argue in favour of one implication of impartialism: that we sometimes have duties to take steps to form new special relationships, in order to fulfil the special duties thereby incurred.

\section{Partialism}

\subsection{Relationships Partialism}

According to 'relationships partialism,' relationships are the final ground of justifications for special duties. Kolodny $(2003,153)$ schematises relationship-grounded reasons as follows: ' $\mathrm{b}]$ ]ecause of the relation that A bears to the relationship $\mathrm{r}$ that he has with $\mathrm{B}$-namely, that $\mathrm{A}$ is a participant in $\mathrm{r}-\mathrm{r}$ provides $\mathrm{A}$ with reasons that it does not provide to some $\mathrm{C}$ who does not bear that relation to r.' According to Kolodny (2010a; 2010b), relationships generate partiality reasons when they have the right kind of history: a certain pattern of encounter, including shared experiences, where the totality of encounters means more than the sum of the parts and where the encounters tend not to wrong anyone. ${ }^{7}$ For Scheffler (2001, ch. 6, esp. 103-4; 2010, 140-5), a relationship generates special duties if the relatives have good reason to non-instrumentally value it. Blum $(1986,354)$ similarly claims that 'we feel that particular relationships are not simply generators of agent-neutral good, but are rather expressive of a good which is internal to those special relationships; and that the moral dimension of those relationships, as generators of reasons for action, is bound up with this particularity, at least the particularity of that type of relationship.'

These justifications capture commonsense intuitions about special duties. However, they 'bottom out' in an unsatisfactorily shallow place. They do not tell us why some histories (e.g. between friends) give reasons for more partiality than others (e.g. between dentist and patient); or what a good reason is to non-instrumentally value a relationship. (Wellman (2000, 552-3) expands on this objection.) Kolodny (2010b, 185) discusses 'trivial interpersonal relationships that no one imagines provide reasons for partiality,' such as always boarding a train when another is leaving. But why is this trivial? To answer would require going beyond the relationship itself, for example, by explaining the relationship's effects on its participants or on others. Now, partialists' key claim is that the explanation cannot possibly go further: the reasons are primitive or brute. So to demand that they go further is to beg the question against their view. My point is that, if one has the urge to ask more 'why' questions than the relationships partialist can answer, then one should look further afield for justifications for special duties.

Additionally, 'relationships are basic moral reasons' is generally suspect. Relationshipssimilarly to food and shelter - are not clearly valuable in themselves. What matters are the people that partake in them. A father should not think 'my daughter is upset; I must comfort her for the relationship's sake, or out of concern for the relationship!' but rather 'Katie is upset; I must comfort her for her sake, or out of concern for her!' (Pettit 1997, 155.) The relationships partialist might, however, agree that one should act for one's relative's sake, while maintaining that the relationship produces the reason why one should act for their sake. The relationships partialist then must separate moral justification (the relationship)

\footnotetext{
${ }^{7}$ Kolodny $(2003$, 180-1) explicitly does not argue that partiality reasons are moral reasons. But we can imagine his view being extended to generate moral justifications. I am here considering such an extension.
} 
from moral motivation (the relative). This is a bad result for a view whose initial appeal lay in the fact that its justification for partiality adhered to our everyday motivations for partiality. If its justification turns out to be different from our everyday motivation, then the relationships view loses its initial intuitive appeal. ${ }^{8}$

\subsection{Individuals Partialism}

Partialists can reject relationships-as-moral-reasons by endorsing the 'individuals' justification, on which special duties are grounded in the identity or non-relational properties of our relatives. Here, one might build on Frankfurt's $(1988,170)$ view that the 'focus of love' is 'the specific particularity that makes his beloved nameable - something that is more mysterious than describability, and that is in any case manifestly impossible to define.' This seems to capture the 'Katie is upset!' intuition outlined above, and it certainly gets something right: persons are morally valuable. However, perhaps by definition, all persons are morally valuable. To narrow down those to whom we have special duties, it must be either that individuals are partiality-worthy independently of their properties, or that their properties make them partiality-worthy. Under the former, Katie would be owed the same special duties if she turned evil. That seems incorrect. Yet under the latter, Katie's father has the same duties to Katie that he has to anybody who is sufficiently similar to Katie. But similar in what respects? Not those for which he values her-her wit, intelligence, or beautybecause those are morally arbitrary. They are explanations and motivations for liking a person, but they are not moral justifications for being partial towards a person.

Similarly for Velleman (1999), our relatives deserve partiality on the basis of their priceless value. They possess this value in virtue of being persons, so this type of value is possessed by every person. However, we have loving (and therefore partial) responses to our relatives' priceless value, but not to non-relatives' priceless value, because we are able to glimpse our relatives' priceless value as a result of our attraction to their (amoral) properties such as their wit, beauty, and so on. This view seems to make partiality a regrettable sideeffect of our inability to love everyone - our inability to perceive everyone's priceless value - rather than something that is morally demanded. If all persons have priceless value, surely we should (if we can) endeavour to love all—or at least more-persons. Our currently blinkered partiality practices appear unjustified.

We could fix individuals partialism by saying that individuals' morally valuable properties give others special duties to them, such that we have special duties to, perhaps, virtuous people. This gives us an 'irreducible-value-of-some-individuals' justification for special duties. However, it does not justify the special duties of commonsense morality. If virtues generate special duties, then (a) our special relatives are not the only ones picked out; and (b) some of our special relatives are not picked out. That our special relatives are not especially virtuous is not usually taken to undermine our special duties to them.

None of this shows that either of these partialist views are false. I do not claim to have refuted them, but to have motivated the search for a different justification. All else being equal between theories of duties, we should plump for the one that that can tell us in any given case whether we have the duties (which 'reasonably non-instrumentally valued relationship,' 'certain type of history,' or 'the individual's identity or relevant properties' cannot) and that can give a satisfactory justification of the duties. Impartialists, I will suggest, can provide this.

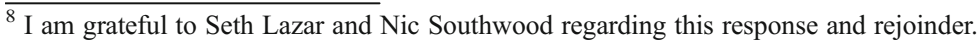




\section{Impartialism}

\subsection{General Structure}

Adapting an argumentative structure given by Kolodny (2010a, 40-1), we can think of impartialists as supporting the claim

(1) one has duties to be partial to one's special relatives

by appeal to EITHER an impartial, purportedly basic normative principle like

(2a) one has a duty to promote general wellbeing

and the non-normative claim that

(3a) partiality to relatives promotes general wellbeing

OR an impartial, purportedly basic normative principle like

(2b) one is morally permitted to act only on universalisable maxims

and the non-normative claim that

(3b) not being partial to one's relatives is not universalisable. ${ }^{9}$

\subsection{Consequentialist Impartialism}

One can certainly question whether (2a) is the principle of morality. But let us accept that we have at least a pro tanto duty to promote wellbeing. Can special duties be explained in terms of this duty? That is, is (3a) true? Special relationships are ongoing, and their partiality is an ongoing practice. So let us focus on consequentialisms that assess partial practices, rather than partial acts, in terms of (2a). ${ }^{10}$ 'Partial practices' might be relationship-specific (each relationship has one practice (Cocking \& Oakley 1995)), agent-specific (each agent has one practice (Mason 1998; Tedesco 2006)), or perhaps community-specific (each community has one practice). I remain agnostic on this - though it will be important for my later argument that individuals can override practices to the extent of making decisions to attempt to end, or begin, special relationships.

Why might (3a) be true? Perhaps relatives know best what constitutes each other's wellbeing, or are most motivated to improve each other's wellbeing, so there are aspects of wellbeing that only relatives can promote or that relatives can promote most efficiently. For example, perhaps by being partial to our special relatives, we become experts those persons' wellbeing. Perhaps this expertise makes special relatives the most efficient promoters of each other's wellbeing. There might also be some goods that are necessarily tied to being in a special relationship - the goods of ongoing love, care, and support, for example. These goods promote individuals' wellbeing, but receiving them arguably requires partiality

\footnotetext{
${ }^{9}$ There may be candidates for (2c), (2d), and so on. For example, Owens (2012) suggests that special duties are justified by serving our 'normative interests.' So we could imagine $2 c$ : one has a duty to promote (or respect or fulfil or...) the normative interests of oneself and others and $3 \mathrm{c}$ : special duties are the best way to promote (or respect or fulfil or...) the normative interests of oneself and others. I take (2a) and (2b) to be the principles most commonly appealed to by impartialists.

${ }^{10}$ I remain agnostic on whether the best consequentialist practice can include wrong acts, or whether all acts included in the best consequentialist practice are right, by virtue of being part of that practice.
} 
amongst special relatives. Additionally, perhaps partiality allows agents to avoid getting in each other's way as they would if they each fumblingly tried to promote the wellbeing of any and all persons. And if agents can trust that all will be partial to their respective relatives, then each can reasonably believe that no one's wellbeing is being ignored. (This is a big 'if,' to which I will return in §4.) Versions of this view are advocated in Sidgwick 1907, 427-39; Railton 1984, esp. 164; Jackson 1991; and Keller 2006.

One might deny that the best way to promote general wellbeing is to be partial —or, at least, as partial as most of us are. Surely we would promote wellbeing more effectively if we spent our Sundays at homeless shelters, or doing paid work to give the pay to charity. The consequentialist will agree, but has a reply: given plausible assumptions about human psychology, the most feasible way to promote wellbeing is to endorse partiality. These assumptions are: that we cannot be motivated to care to a comparable degree about nonrelatives, that special relationships cultivate in us compassionate dispositions that are arguably necessary for us to care at all about non-relatives, and that without special duties we would be depressed and unable to promote any wellbeing (Ashford 2000, 436-9). If this is right, and if ought implies can, then impartial principles can only constrain partiality to the extent that such psychological constraints allow. Within the bounds of these constraints, however, the only moral principles in play are impartial ones.

Of course, there are some well-known objections to this consequentialist position. I will canvas them in $\S 3.4$, along with objections to Kantian impartialism. I now turn to the latter.

\subsection{Kantian Impartialism}

While the most ardent impartialists about special duties are consequentialists, Kantians can make similar moves by considering how special duties square with various 'universalisability' tests. ${ }^{11}$ To test for duties to be partial, we must consider whether it is universalisable to not be partial in certain contexts for certain reasons. If such maxims are universalisable, this suggests an absence of duties to be partial in those contexts for those reasons. Again, let us consider special duties as a practice - consider a set of maxims describing actions of impartiality in certain contexts for certain reasons. Consider, for example, a set of maxims on which grown children do not visit parents in hospital, friends do not comfort friends when they're upset, and so on, in contexts where this would require partiality of the child or friend, and for reasons such as that the child or friend has other, notterribly-weighty demands on their time and energy (these other demands might derive from moral values other than partiality, or from non-moral values such as prudence or etiquette). We have to ask whether it is universalisable for agents to act impartially in these contexts for these reasons.

First, we might ask: would it be self-defeating or inconsistent for me to will my acting (successfully) in accordance with this maxim and everyone else's acting on the same maxim? Consider maxim M: 'not visiting my friend in hospital in order to prepare a lecture I'm giving one week from now.' It seems that being someone's friend just is, in part, not to act in accordance with M. Consider other M-like maxims, such as 'not comforting my friend so as to be relieved of my mild headache,' and so on. If $\mathrm{M}$ and $\mathrm{M}$-like maxims were universalised - if everyone acted on them - then, arguably, there would be no friends. This is because being someone's friend just is, inter alia, not acting on those maxims. We are now imagining a world in which there are no friendships, because people act in accordance with

${ }^{11} \mathrm{I}$ am here talking about a broadly Kantian approach, focusing just on universalisability. The nuances of Kant's views on partiality are discussed in Cottingham 2010. 
$\mathrm{M}$ and M-like maxims. But abiding by these maxims entails that there are friends, otherwise there would be no friends to not visit in hospital, not comfort, and so on. So, a world in which $\mathrm{M}$ and M-like maxims are universalised seems to a world in which there friends both existent and do not exist: an impossible world. ${ }^{12}$

Suppose one denies that friendship would cease to exist in a world where everyone acted on $\mathrm{M}$ and M-like maxims. Still, it is plausible that the agent would be unable to act on those maxims, in a world in which the maxims were universalised, so as to achieve the purposes (that is, respond to the reasons) specified in the maxims - for example, writing a lecture, being relieved of a mild headache, or so on. If $\mathrm{M}$ and $\mathrm{M}$-like maxims were universalised, children would run wild, being the special responsibility of no one. For lack of special attention, infants would die, adults would be depressed, and many people would fail to be born (since the lack of partiality between caregivers would make people unlikely to commit to raising children). Certainly, the universalisation of $\mathrm{M}$ on its own is unlikely to produce such a world. But we're considering a set of maxims that describe actions of impartiality to relatives in certain contexts for certain reasons. It's doubtful that, in such a world, there would be the demand or motivation for lecture-writing, or that one could find relief from headaches simply by not tending to special relatives. The agent's purposes (i.e., attending to the not-terribly-weighty countervailing reasons) would be frustrated in such a world. That is, the agent is only able to ignore his special duties in order to, say, write a lecture, because most other agents do not do this. If everyone abided by $\mathrm{M}$ and M-like maxims, there would likely be no lectures to write. So, if these maxims were universalised, the agent's own ends would be frustrated. ${ }^{13}$

To these universalisability tests, we might add Scanlon's: '[a]n act is wrong if its performance under the circumstances would be disallowed by any set of principles for the general regulation of behaviour that no one could reasonably reject as a basis for informed, unforced, general agreement' (Scanlon 1998, 153). ${ }^{14}$ Scanlon's emphasis is not on what the agent could will, but on what others could (reasonably) refuse to include on a list of principles on which we all agree to act. Scanlonian contractors, it seems to me, could reasonably reject principles that permit impartiality in certain contexts. To see this, imagine yourself lying alone in hospital for days. Ask whether you would reject a set of principles permitting friends not to visit you so that they can write non-urgent lectures instead. Of course, there are many principles that the world's starving could reasonably reject, and many pro-partiality principles are amongst them (Ashford 2003). But it is plausible that some partiality is required from a Scanlonian perspective.

\subsection{The Classic Objection to Impartialism}

One might think the impartialists have identified the wrong justificatory reasons. If your friend discovered that you visited her in hospital not because you cared about her but because doing so promoted general wellbeing, or because not doing so was not universalisable, she would rightly be shocked (Stocker 1976, 462; Blum 1980, 142-3). The reason to visit one's friend derives from the role they have played and continue to play

\footnotetext{
12 This mirrors Korsgaard's (1985) discussion of false promising and logical contradiction. Friendship is easier apply to this test than, for example, parent-child relationships. One might think that there can be a parent-child relationship, even if one party (but, I suspect, not the other as well) consistently fails to fulfil the duties entailed by the relationship.

13 This universalisability test derives from Korsgaard's (1985) preferred test.

${ }^{14}$ Scanlon sees friendship (and possibility other special relationships) as beyond the scope of this principle. I include it here for formulaic completeness.
} 
in one's life. The focus should be on particular relationships between particular individuals, not on moral principles (Held 2006, 80).

In response, the impartialist might accept that you should be motivated by love, even though this love is justified is because it promotes general wellbeing or is universalisable. (Those who endorse duty as the right motivation may be unable to make this move.) Earlier, I noted that this move is also open to the advocate of relationships partialism. However, the advocate of relationships partialism then had to give up an important virtue of her account: that justification accords with phenomenology. The impartialist also has to give this up, but in doing so they retain other theoretical virtues that relationships partialism does not have. First, their moral theory is more unified: the final justification for special duties is the same as the final justification for at least some other kinds of duties. Second, the reductive justifications make impartialists' theory determinate: the impartialist accounts pick out not only which relationships require partiality, but also with respect to what, and how much, partiality they require - that is, as much as needed to adhere to impartial principles.

Yet there is a catch-22: if the agent knows that partial motivations are justified because of impartialism, he seems to fail to have partial motivations fully. So he fails to have the motivations impartialism demands he have. But if he has partial motivations unreflectively and acts on them, the impartialist should negatively evaluate his internal states: he does not know he has done right. Either way, he has done wrong. Impartialists might instead be self-effacing, and recommend unreflectively acting on partial motivations - bizarrely stating agents can only do right if they do not know it. These are odd-perhaps 'schizophrenic'-psychological demands (Stocker 1976).

Yet their oddness is not inconsistent or implausible. Simply, one can miss a goal by aiming at it: one can fail to promote impartial value by having that value in mind. In this way, adhering to impartial principles by acting out of love in personal relationships is akin to falling asleep. The best way to fall asleep is not to think about falling asleep. Similarly, the best way to adhere to impartial principles is not to think about adhering to those principles. Alternatively, perhaps one can have multiple motivations for the same action, where the motivations are complementary and additive. Thus, one could be motivated by love and by impartial moral principles: together, they might overdetermine that one performs a certain action, or add up to sufficient reason for one to perform it. Along these lines, Liao $(2006,19)$ imagines a professional cook who is motivated to prepare delicious dishes for his friend both because he is hired to do so and because he wants to do it for his friend. A third possibility is that impartial principles make caring motivations good justifications for actions and attitudes. On this view, the impartial principles are second-level justifications, while caring motivations are first-level justifications. Second-level justifications make first-level justifications good justifications (Southwood 2010, 177-9).

In any case, commonsense recommends that we periodically adopt an impartial justificatory perspective on our partiality (Baron 1991). If, after weeks of trying to comfort your emotionally traumatised friend, you reflect that you wouldn't endorse others' acting in this way for a relevantly similarly placed friend, or that doing so is not the best way to promote wellbeing, then you should consider stopping dividing your time in such a partial way. Switching between the motivational and justificatory levels, or the first- and second-level justifications, for either consequentialist or Kantian reasons, is not schizophrenic. It is something we all do as we reflect upon and change the way we treat others. 


\section{Forming Special Relationships}

\subsection{The Problem}

One of the main impartialist objections to partialism is that, under a partialist lens, special duties are arbitrarily exclusive (Scheffler 2001, 108). Under impartialist justification, special duties are still exclusive: they entail partiality and partiality entails exclusivity since it is conceptually impossible to be partial to everyone. But-impartialists argue - under impartialist justification special duties are not arbitrarily exclusive.

The arbitrariness of partialism consists in the fact that partialism ignores the moral claims of those who are not already in special relationships. Practices of partiality are bad for, or wrongful to, someone who does not receive partiality from anyone. For a consequentialist, they are bad or wrongful because such a person's wellbeing is not promoted by special duties. (For a maximising, aggregating consequentialist, this can have wider ramifications, such as the excluded person's subsequent lack of motivation to promote others' wellbeing.) For a Kantian, this is bad or wrongful because we could not universalise people's not receiving partial treatment. According to impartialists, then, partialist justifications exclude people from receiving partiality for no good reason. It excludes them because they happen not to have the right history with anyone else or because no one else happens to value their identity or properties. Impartialist justifications, on the other hand, allow people to be excluded only if such exclusion adheres to impartial principles.

Yet what does this impartialist objection to partialism say about our current practices of partiality, that is, about the special duties recognised by current social convention? As things stand, some receive more partiality than others, simply because others enjoy their company more. Additionally, because we are partial to those we know, and tend to know those who are similarly materially well-off to us, those who are well-off are partial towards those who are well-off. But impartialists must endorse any and only (a) practices of partiality that promote wellbeing, or (b) practices of partiality that are universalisable. Impartialists must be concerned with practices of special duties because the justifications that they gave for special duties had to do with either (a) the way whole systems of special duties promote wellbeing; or (b) partiality in general could be universalised. It is likely that, as a matter of empirical fact, current partiality practices do not meet either of these criteria. If partiality is required because of impartialist justifications, then we have a moral reason to change our partiality practices to ones that adhere to impartial principles.

\subsection{An Individual Solution}

If we think that partiality is required for impartialist reasons, then we have a moral reason to be proactive in changing our distribution of partiality, if this will promote wellbeing or give partiality a basis that is universalisable. The upshot of this for impartialists is that there are duties to take action or take on costs to bring about a distribution of special duties that is true to impartialist justifications. (That is, true to whichever impartialist justification ones finds most plausible.) Impartialists are committed to the following:

(i) An agent has an all-things-considered moral duty to take actions or adopt attitudes that increase the chance of his forming a special relationship with a person and fulfilling the special duties thereby incurred; unless

(ii) impartial principles are best adhered to by his to taking actions or adopting attitudes that increase the chance of his forming a special relationship with (and fulfilling the 
special duties thereby incurred to) a different person, in which case he has an allthings-considered moral duty to take those actions or adopt those attitudes; or

(iii) impartial principles are best adhered to by his taking actions or adopting attitudes that increase the chance of two persons, neither of whom is himself, forming a special relationship with each other and fulfilling the special duties thereby incurred, in which case he has an all-things-considered moral duty to take those actions or adopt those attitudes; or

(iv) impartial principles are best adhered to by his taking actions and adopting attitudes that do not have the aim of increasing the chance of any special relationship being formed and the duties thereby incurred being fulfilled.

I will call this the 'relationship-forming duty.' But note that it is not enough that one merely creates new relationships. The special duties thereby incurred must also be fulfilled, since it is precisely the value of these duties' fulfilment (i.e., the value of partiality in certain contexts) that gives rise to the value of forming such relationships.

Yet partialists, too, should recognise relationship-forming duties, at least in pro tanto form. No partialists (of which I am aware) think that the reasons irreducibly grounded in special relationships or special relatives are the only moral reasons. Partialists tend to think that irreducibly partial principles need to be balanced against impartial principles. And partialists seem to think that the irreducibly partial principles apply to special relationships only once those relationships have been formed. If at least some of our actions should be guided by impartial principles, and if irreducibly special duties hold only once special relationships are underway, then there is scope for impartial principles' constraining relationship-forming steps. If partialists want to deny that impartial principles constrain these relationship-forming steps, they will have to justify this. And in doing so, they will not be able to appeal to the irreducible reasons that arise once relationships have been formed, because those reasons will not yet have arisen for the person who is considering taking relationship-forming steps.

\subsection{Applications and Clarifications}

The relationship-forming duty is perhaps easiest to accept for friendships. For other kinds of relationships, things may be complicated. For example, in order to increase the chance of developing a romantic relationship, certain conditions might be required that are beyond the agent's control: some minimal level of sexual attraction, for example. This requirement plausibly arises out of more or less hard constraints on humans' ability to practice the kind of partiality particular to romantic relationships: perhaps humans are just the kinds of things that cannot be partial in the ways characteristic of romantic relationships unless certain minimal conditions of compatibility are met.

Relationships between parents and children are another interesting case. My argument implies that there are sometimes duties to adopt children, or convince others to adopt children, perhaps instead of having one's own children. I embrace this implication, assuming that parents can provide adoptive children with the extent and type of partiality they can provide biological children. Perhaps this is not true of all parents or potential parents. For some, there may be nothing they or others can do to increase the chance of their forming a parent-child relationship with someone who is not their biological child. For others, however, there are duties to consider impartial principles when it comes to deciding who one will form a parent-child relationship with (placing non-identity problems to one side). 
The argument applies more straightforwardly to co-nationals: if one's partiality to conationals over non- co-nationals does not promote wellbeing or is not universalisable, then one should change those practices. Certainly on consequentialist grounds, and probably on Kantian ones, this will require a redirection (to non- co-nationals) of the partiality most of us show co-nationals. And the argument will have interesting implications if it turns out that there are some goods that we typically give co-nationals that cannot adequately be redirected by the standardly-recommended money transfers or restructures of the global economic system. For example, we tend to care more if our co-nationals are killed in violent conflict than if non- co-nationals are. If such practices do not stand up to impartial scrutiny, this will require us to take action in our personal ethical lives to transform our attitudes, and not merely our monetary transfers, to non- co-nationals.

Condition (iii) has interesting upshots for intervention in the lives of others. The duty to increase the chance of two persons, neither of whom is oneself, forming a special relationship implies a duty to play 'matchmaker.' This appears unpalatable. However, this duty arises only if it is the best way to adhere to impartial principles. Because there are many things we value other than special relationships and partiality, this is unlikely to occur very often. Autonomy, non-interference, non-deception, and the right to privacy might be core values in one's impartialist ethic, which limit how often the duty in (iii) arises (the same goes for the duty in (i)).

Of course, relationship-forming duties will inevitability inhibit certain values, such as freedom of personal association. Yet this is not so odd: many duties inhibit this freedom, and many of these duties demand the same kinds of actions as relationship-forming duties. For example, imagine yourself driving through the desert in a fully-stocked utility vehicle, and coming across a stranded stranger. Under most ethical theories, you have a duty to assist the stranger: maybe to drive them to the nearest town, let them stay with you, or give them a meal. The only difference between that duty and relationship-forming duties is that the latter derive not from the stranger's need for immediate assistance, but rather from the value of the relationship that might result. The actions the duties demand will, in many cases, be similar.

Also, note that the duty is just to increase the chance of a process succeeding whereby a relationship develops organically. Special relationships are two-way streets: one cannot form or stay in a special relationship on one's own. One can only make it likely. Exactly when the duty arises will depend on how partiality weighs up against the other values in one's impartialist ethic, such as freedom of association and so on. The duty is also not to form or stay in relationships under duress of duty, precisely because such relationships would fail to adhere to impartial principles. Because we are always already embedded in special relationships, impartial principles might demand that we stay in at least some of those relationships.

One might insist that my proposal demands us to increase the chance of special relationships for the wrong reasons. These reasons are wrong because they inhibit, or even preclude, real special relationships. Real special relationships, and real special relatives, not only must be non-instrumentally valued once the relationship gets going. They must be noninstrumentally valued from the start. There are two replies to this.

First, impartialism does not necessarily exclude forming relationships for amoral reasons, such as that one likes a person. Statements (i)-(iv) are criteria of rightness rather than, necessarily, a decision-making procedure. Since impartialists can separate motivation and justification, or first-order and second-order reasons, one can abide by impartial principles even if one takes steps to form a special relationship just because one likes the new relative or non-instrumentally values them. Indeed, liking them could be part of what makes the duty in condition (i) — rather than that in (ii) or (iii) — hold. If you didn't like them, then increasing 
the chance of having a relationship with them might be prohibited by the values of your impartialist ethic, for example if doing so would require deceiving them or taking on cost that is (according to one's impartialist ethic) disproportionate.

Second, though, moral reasons are sometimes perfectly good motivational or first-order reasons for forming relationships. If, months after moving to a new city, a friend tells you 'You know, I made an effort to be especially considerate of you when you first moved here because you seemed lonely,' this would not seem like the wrong reason. (Perhaps it would have been wrong for them to have said so when you first met, but the impartialist can agree with this: to have said so would have inhibited the friendship.) As stated in $\S 3.4$, one can have multiple complementary and additive motivations for the same action. One can become someone's friend both because one likes him and because he seems like he needs a friend.

One might then maintain that relationship-forming duties serve as a reductio of the idea that special relationships are any of morality's business. One might thus side with Wolf (1982) in believing partiality and special relationships to be beyond morality's scope. For those prepared to hold that we do nothing morally wrong when we treat friends like strangers, the duty to form special relationships will not hold sway. But, as I noted in $\S 1$, the demands that derive from special relationships have a distinctively moral feel. These demands invite reactive attitudes, are comparatively weighty, and appear to be categorical. Perhaps such relationships beyond the scope of morality - but this is not what our intuitions tell us. And impartialists give a good account of how special relationships fall within morality's scope. It is then up to the amoralists to give a principled account of how and why special relationships escape moral assessment. And for those who allow impartial morality to constrain special relationships even to some extent, they will have to explain how the formation of such relationships escapes these constraints.

A final clarification is that my argument is consistent with current practices allowing for too much partiality (Singer 1972; Ashford 2003). We are required to be partial to those who are such that, if we are partial to them, we adhere to impartial moral principles. Just who those people are - and how many (or few) of them there are - is up for grabs. My point is that, as well as constraining how much partiality is required, impartial morality also constrains towards whom partiality is required.

\subsection{An Institutional Solution}

One might wonder whether the individual solution in $\$ 4.2$ is the best solution. Perhaps, instead or as well, governments or other organisations should ensure that everyone receives the partiality that impartial principles say they deserve (Goodin 1988). However, it's doubtful that governments could ensure this for all the partialitytypes I have been discussing. They could do it for the partiality typical of co-national relationships (governments already engage in nation-building), but it is unclear how this would work for the partiality typical of friends, family, romantic partners, and so on. Can we imagine governmental policies bringing about impartially-justified partiality practices within these relationships? Perhaps we can. Brighouse and Swift (2008) focus on parents' treatment of children, and argue on egalitarian grounds that the state ought to limit the legal scope for such treatment, for example by disallowing private schools or imposing hefty taxes on inheritance. This, they argue, would allow the goods that arise in special relationships to be more fairly distributed. However, according to my argument, it is not enough that partiality is limited. It must also be redirected. One might then imagine policies that foster new special relationships, such as support groups for those who want special relationships but lack them. 
However, recall that for consequentialists the rationales for (3a) depended on us caring deeply about our relatives, thus being greatly motivated to assist them and learn about their wellbeing; on relationships making us feel fulfilled and be compassionate, so that we become more beneficent in other spheres of life. Taking significant steps towards increasing the chance of such relationships is a lot of ask of governments. Similarly for Kantians, the maxim that was up for universalisability was 'not being partial to one's special relatives'. Special relatives are valued non-instrumentally, take each other's interests as their own, and value a whole package of each other's properties. If the state assigned or promoted special relationships, then most of them are unlikely to have these features. Thus the question of partiality special relatives would remain for the Kantian. In short, I suspect that state policies would be insufficient for producing impartially demanded partiality practices, if people disregarded impartialist constraints on partiality once the policies were in place. If this is right, relationship-forming duties are a necessary component of any solution to the problem of arbitrary exclusion in partiality practices.

This is not to say that an institutional component might not also be necessary. ${ }^{15}$ Above, I claimed agnosticism about whether partiality practices are agent-specific or community-specific, though I assumed that individuals can override those practices to fulfil relationship-forming duties. This presents a problem. If partiality practices are community-specific, then individuals might have a hard time fulfilling the relationshipforming duty. Consider a society which has a strong taboo against friendships between persons of different classes. Suppose that any given person in this society cannot do much at all to fulfil relationship-forming duties regarding those outside his or her class. Yet suppose the correct impartialist principle would be adhered to only if the community's practice were different, such that each were able to fulfil the relationshipforming duty regarding those outside one's class.

Depending on how valuable the newly formed relationships would be, my individual solution might imply that each individual has a duty to take steps to reform her community's practices, so that she can increase the chance of forming a special relationship with someone outside her class. That is, community reform might be part of her relationship-forming duty. If so, then she can increase the chance of forming a special relationship with someone outside her class, in the long term: she can engage in social reform, and then take steps regarding the specific relationship. Both of these steps increase the chance of the relationship forming. At $t_{1}$, she can have a duty to take steps to form the special relationship, even if she will only be able to do anything specifically regarding the relationship at $t_{3}$, which is after she has engaged in social reform at $t_{2}$.

However, individuals can rarely reform their communities at all on their own. It might then be that the individual really cannot increase the chance of forming a special relationship with someone outside her class, even over a very long period of time, no matter how much she attempts social reform. In that case, she cannot have a duty to do so. Here, an institutional or collective solution is likely to be a necessary, though not sufficient, condition for individuals' partiality practices to adhere to impartial principles. Just how people (together, separately, or through institutions) would need to go about such reform of community practices is a question with which I cannot engage here. To this extent, my argument should be seen as primarily targeted at individuals within fairly socially liberal communities.

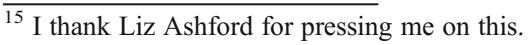




\section{Conclusion}

Do we have moral reasons to be partial to special relatives, that is, do we have special duties? Commonsense says that we do. But why? I have suggested that these duties are not adequately justified by appeal merely to special relationships or special relatives. Yet impartial justifications can ground and circumscribe special duties in a coherent and satisfying way. These justifications entail that we have duties to perform actions and adopt attitudes that increase the chance of special relationships being formed, just in case the fulfilment of the special duties within those special relationships would adhere to impartialist principles. These duties are not as counterintuitive as they may first appear, and it is possible that certain biological, psychological, institutional, and social preconditions must be in place before they are triggered. Still, the upshot is that most of us should think much more carefully, and much more morally, about who our special relatives should be.

Acknowledgements For helpful comments, I thank Bob Goodin, Nic Southwood, Liz Ashford, Jonathan Farrell, Luara Ferracioli, and audiences at the Australian National University and the 2012 meeting of the British Society for Ethical Theory.

\section{References}

Ashford E (2000) Utilitarianism, integrity, and partiality. J Philos 97(8):421-439

Ashford E (2003) The demandingness of Scanlon's contractualism. Ethics 113:273-302

Baron M (1991) Impartiality and friendship. Ethics 101:836-857

Blum L (1980) Friendship, altruism and morality. Routledge \& Kegan Paul, London

Blum L (1986) Iris Murdoch and the domain of the moral. Philos Stud 50:343-367

Brighouse H, Swift A (2008) Legitimate parental partiality. Philos Public Aff 37:43-80

Cocking D, Oakley J (1995) Indirect consequentialism, friendship, and the problem of alienation. Ethics 106:86-111

Cottingham J (2010) Impartiality and ethical formation. In: Feltham B, Cottingham J (eds) Partiality and impartiality: morality, special relationships and the wider world. Oxford University Press, Oxford, pp 65-83

Frankfurt H (1988) The importance of what we care about. Cambridge University Press, Cambridge

Goodin RE (1988) What is so special about our fellow countrymen? Ethics 98:663-686

Held V (2006) The ethics of care: personal, political, and global. Oxford University Press, New York

Jackson F (1991) Decision-theoretic consequentialism and the nearest and dearest objection. Ethics $101: 461-482$

Jones WE (2012) A lover's shame. Ethical Theory Moral Pract 15:615-630

Keller S (2006) Four theories of filial duty. Philos Quart 56:254-274

Kolodny N (2003) Love as valuing a relationship. Philos Rev 112(2):135-189

Kolodny N (2010a) Which relationships justify partiality? The case of parents and children. Philos Public Aff 38:37-75

Kolodny N (2010b) Which relationships justify partiality? General consideration and problem cases. In: Feltham B, Cottingham J (eds) Partiality and impartiality: morality, special relationships and the wider world. Oxford University Press, Oxford, pp 169-193

Korsgaard C (1985) Kant's formula of universal law. Pac Philos Quart 66:24-47

Liao M (2006) The idea of a duty to love. J Value Inquiry 40:1-22

Mason E (1998) Can an indirect consequentialist be a real friend? Ethics 108:386-393

Owens D (2012) The value of duty. Proceedings of the Aristotelian society supplementary volume, LXXXVI: 199-215

Pettit P (1997) Love and its place in moral discourse. In: Lamb R (ed) Love analyzed. Westview Press, Boulder, pp 153-163

Railton P (1984) Alienation, consequentialism, and the demands of morality. Philos Public Aff 13(2):134-171

Scanlon T (1998) What we owe to each other. Belknap, Harvard

Scheffler S (1997) Relationships and responsibilities. Philos Public Aff 26:189-209 
Scheffler S (2010) Morality and reasonable partiality. In: Feltham B, Cottingham J (eds) Partiality and impartiality: Morality, special relationships and the wider world. Oxford University Press, Oxford, pp 98-130

Scheffler S (2001) Boundaries and allegiances: Problems of justice and responsibility in liberal thought. Oxford University Press, Oxford

Sidgwick H (1907) The methods of ethics, 7th edn. Indianapoils, Hackett

Singer P (1972) Famine, affluence, and morality. Philos Public Aff 229-243

Southwood N (2010) Contractualism and the foundations of morality. Oxford University Press, New York

Stocker M (1976) The schizophrenia of modern ethical theories. J Philos 73:453-466

Tedesco M (2006) Indirect consequentialism, suboptimality, and friendship. Pac Philos Quart 87:567-577

Velleman J (1999) Love as a moral emotion. Ethics 109:338-374

Wellman C (1997) Associative allegiances and political obligations. Soc Theory Pract 23(2):181-204

Wellman C (2000) Relational facts in liberal political theory: Is there magic in the pronoun 'my'? Ethics 110:537-562

Wolf S (1982) Moral saints. J Philos 79(8):419-439 